\title{
UTILIZATION OF SALT WHEY FROM EGYPTIAN RAS (CEPHALOTYRE) CHEESE IN MICROBIAL MILK CLOTTING ENZYMES PRODUCTION \\ El - Tanboly, E. E. ${ }^{\star \star}$; M. El-Hofi**; Y. Bahr ${ }^{\star \star}$; W. I. El-Desoki ${ }^{\star}$ and \\ Azza Ismail ${ }^{\star *}$ \\ * Faculty of agriculture, El-Azhar University, Assiut, Egypt. \\ ** Dairy sciences, National Research Centre, Dokki, Cairo Egypt., tanboly1951@yahoo.com
}

\section{ABSTRACT}

Microbial milk-clotting enzymes are valued as calf rennet substitutes in the cheese industry. Mucor pusillus QM 436 was identified to produce the highest milkclotting activity during screening of 19 fungal strains. Salted whey resulting from Ras (Cephalotyre) cheese manufacture as a whole medium for growth of Mucor pusillus QM 436 and production of the enzyme. The milk-clotting enzyme from Mucor pusillus QM 436 was purified to 7.14 -fold with $54.4 \%$ recovery by precipitation in ammonium sulfate, ethanol and fractionated by gel filtration on Sephadex G-100. The enzyme was active in the $\mathrm{pH}$ range 5.5-7.5 and was inactivated completely by heating $5 \mathrm{~min}$ at $70^{\circ} \mathrm{C}$ and $30 \mathrm{~min}$ at $65^{\circ} \mathrm{C}$. The highest level of enzyme activity was obtained at $60^{\circ} \mathrm{C}$, $\mathrm{pH}$ 5.5. A positive and proportional relationship occurred in presence of CaCL2 in milk, with inhibition occurred in presence of $\mathrm{NaCl}$. The high level of milk-clotting activity coupled with a low level of thermal stability suggested that the milk-clotting enzyme from Mucor pusillus QM 436 should be considered as a potential substitute for calf rennet.

Keywords: Milk-clotting enzymes, Mucor pusillus QM 436, Ras cheese , Salted whey, purification.

\section{INTRODUCTION}

Calf rennet as a traditional milk-clotting enzyme is very important in the production of cheese. The enzyme clots milk and has an important role in the process of cheese maturation Kumar et al. (2005). Calf rennet has traditionally been used by the dairy industry for the manufacture of cheese with good flavor and texture. The worldwide increase of cheese production coupled with a reduced supply of calf rennet has prompted a search for calf rennet substitutes, including microbial and plant rennets Cavalcanti et al .(2004). However, most plant rennets have proved unsuitable because they impart a bitter taste to the cheese. Microbial rennet appears to be more promising because its production is cheaper, biochemical diversity is greater, and genetic modification is easier. Many species of microorganism are known to produce a milk-clotting enzyme that can potentially substitute for calf rennet, and Rhizomucor pusillus, Rhizomucor miehei, Endothia parasitica and Irpex lactis are used extensively as sources of milk-clotting enzymes in the manufacture of cheese O'Leary and Fox (1974) and Kurutahalli et al. (2010). It is well accepted that discharging of whey from dairy industry as waste creates severe pollution due to its high biological oxygen demand (BOD) (35-40 g/l) Zayed and Winter (1995). Annually, 110 million metric tons of whey is produced worldwide through cheese manufacture Brizinski and Roberts (2002). About 50 percent of Egypt's total milk production is utilized in commercial cheese. Cheese production in Egypt totaled 480,000 metric tons 
in 2001 and accounted for 2.9 percent of the world total cheese. In the 1990s, the whey production in Egypt increased steadily by about six percent annually and the amount produced in 2000 was 1,452,500 41 metric tons Zhang et al. (2003). Salt whey is produced from Domiati, Ras (Cephalotyre) and Cheddar cheese making. The salt level in whey from Domiati cheese is about $8-15 \%$ whereas it is only about $2-5 \%$ in whey from Ras and Cheddar cheese making. Salt whey, unlike sweet whey, cannot be conveniently processed because of its high salinity level Sanderson et al. (1996). Moreover, it has a high biological oxygen demand and chemical oxygen demand, which make its disposal a problem Zayed and Winter (1995). Most cheese manufacturing facilities in Egypt perform land spreading of salt whey. However, this practice increases the chloride levels of soil, and elevates the risk of crop damage. One possible application for salt whey is to use it as a whole medium for growth of fungi. The purpose of the present work has been carried out on 19 cultures of fungi with the object to select a specific strain capable to produce a milk clotting enzyme of suitable mature. Furthermore, the possibility of using salted whey resulting from Ras cheese manufacture as a whole medium for growth was investigated. This by-product however, due to this high salt content, is not recycled in any significant industrial process so far in Egypt.

\section{MATERIALS AND METHODS}

\section{Microorganisms, Stock cultures}

A total of Ninteen fungal strains were obtained from the stock culture collection laboratory of microbial chemistry, National Research Center, Cairo, Egypt. These organisms originally were obtained from various sources as shown in table (1).

Table 1. Fungi cultures assayed for milk clotting activity

\begin{tabular}{|c|l|l|}
\hline No. & \multicolumn{1}{|c|}{ Fungi cultures } & \multicolumn{1}{|c|}{ Code number and source } \\
\hline 1 & Aspergillus oryzae & DSM 633 \\
\hline 2 & Aspergillus niger & DSM 823 \\
\hline 3 & Aspergillus awamori & DSM 734 \\
\hline 4 & Aspergillus flavus & DSM 818 \\
\hline 5 & Aspergillus terreus & NRRL 555 \\
\hline 6 & Aspergillus ochraceus & NRC 67 \\
\hline 7 & Aspergillus vesicolor & NCL \\
\hline 8 & Aspergillus tamarii & NCL \\
\hline 9 & Aspergillus fumigates & NCL \\
\hline 10 & Mucor pusillus & QM 346 \\
\hline 11 & Mucor hiemalis & DSM 63297 \\
\hline 12 & Rhizopus oryazae & DSM 853 \\
\hline 13 & Rhizopus chinensis & DSM6 1834 \\
\hline 14 & Rhizopus stolonifer & DSM 6855 \\
\hline 15 & Rhizopus nigricans & DSM 907 \\
\hline 16 & Penicillium citrinum & DSM 62851 \\
\hline 17 & Penicillium lilacinm & MCL \\
\hline 18 & Penicillium implicatum & MCL \\
\hline 19 & Penicillium verrucosum & MCL \\
\hline
\end{tabular}

DSM: German Collection of Microorganisms Gottigen, West Germany, NRRL:Culture

Collection of Northern Regional Research Laboratory, Peoria, Illinois, USA,

NRC: Culture Collection of National Research Center, Egypt,. QM: University of

Queensland, Brisbane, Australia, MCL: Microbial Chemistry Laboratory, National

Research Center, Egypt. 
All the strains were grown for growth and enzyme production, suspensions from active slants of the organism, grown on Czapek-Dox agar medium, were used for incubation the $300 \mathrm{ml}$. conical flasks, containing 50 $\mathrm{ml}$. of sterile medium of $5 \%$ salted whey. The flasks were incubated on rotary shaker at $30 \pm 4^{\circ} \mathrm{C}$ for 3 days. The cultures were then, harvested by centrifugation at $3000 \mathrm{rpm}$ for $15 \mathrm{~min}$. in a cooling centrifuge (Janetzk, k26 type); the mycelia discarded and the resulting supernatant was used as a source of enzyme.

Medium used for milk clotting enzyme production

Fresh sweet whey was obtained from Sama Milk Co., produced from Ras cheese. The composition of the sweet whey in table (2).

Table 2. The general composition of sweet whey commonly used as a medium for growth of fungi

\begin{tabular}{|c|c|c|}
\hline No. & Compound & Percent (\%) \\
\hline 1 & Water & 92 \\
\hline 2 & Lactose & 5.2 \\
\hline 3 & Lactic acid & 0.05 \\
\hline 4 & Fat & 0.5 \\
\hline 5 & Protein & 1.1 \\
\hline 6 & Ash & 0.5 \\
\hline 7 & Total solids & 8.05 \\
\hline 8 & $\mathrm{pH}$ & 6.4 \\
\hline
\end{tabular}

\section{Milk powder}

Spray dried skim milk powder (high-high treaded grade) made in USA was obtained from Ministry of agriculture, Giza.

\section{Casein}

Casein soluble in alkali was obtained from Adwic.

The milk clotting activity (M.C.A.)

The milk clotting activity (MCA) of the enzyme preparation was measured by the method described by Otani et al. (1991). A $5 \mathrm{~mL}$ portion of the substrate $(12 \%$ skim milk in $10 \mathrm{mM} \mathrm{CaCl} 2$ was incubated for $5 \mathrm{~min}$ at $35^{\circ} \mathrm{C}$ and then $0.5 \mathrm{~mL}$ of enzyme extract was added. The length of time starting from the addition of the enzyme extract to the formation of the first particles was recorded, and the milk-clotting activity was calculated by Kawai and Mukai (1970) as: $S U=2400 \times 5 \times D / T \times 0.5$ (1) Where $T$ is milk-clotting time (s), and $\mathrm{D}$ is dilution of the enzyme. One Soxhlet unit (SU) of milk-clotting activity was defined as the amount of enzyme required to clot $1 \mathrm{~mL}$ of substrate within $40 \mathrm{~min}$ at $35^{\circ} \mathrm{C}$.

\section{The proteolytic activity (P.A.)}

The proteolytic activity (PA) of the purified enzyme was determined with light soluble casein as substrate, following essentially the technique by Otani et. al, [24]. To $2.5 \mathrm{~mL}$ of $1 \%$ casein solution prepared in $20 \mathrm{mM}$ potassium phosphate buffer $(\mathrm{pH} 6.3)$, suitably diluted enzyme solution was added. The mixture was incubated at $35^{\circ} \mathrm{C}$ for $10 \mathrm{~min}$, before adding $2.5 \mathrm{~mL}$ of $0.44 \mathrm{M}$ trichloroacetic acid solution. The mixture was filtered using Whatman no. 1 filter paper. To $1 \mathrm{~mL}$ of this filtrate, $2.5 \mathrm{~mL}$ of $0.55 \mathrm{M}$ sodium 
carbonate and $1 \mathrm{~mL}$ of three times diluted Folin reagent is added. This solution was kept at $30^{\circ} \mathrm{C}$ for $30 \mathrm{~min}$ and absorbance values are recorded at $660 \mathrm{~nm}$. One unit is defined as unit increase in absorbance at $660 \mathrm{~nm}$. Protein concentration was determined by Ohnishi and Barr (1978) using bovine serum albumin as standard.

\section{Enzyme purification}

All enzyme purification steps were done at $4^{\circ} \mathrm{C}$. The crude enzyme was harvested by centrifugation at $8,000 \mathrm{~g}$ for $10 \mathrm{~min}$ and the supernatant was used for the study. The crude enzyme extract was precipitated with ammonium sulfate $(40-80 \%$ saturation). The precipitate obtained after centrifugation was suspended in $50 \mathrm{mM}$ sodium phosphate buffer $(\mathrm{pH} \mathrm{6.0)}$ and dialysed overnight against several changes of distilled water to remove the salt. Five milliliters of the partially purified enzyme solution were sub jected to Gel Sephadex G-100 column $(30 \mathrm{~cm} \times 2.6 \mathrm{~cm})$ pre-equilibrated with $50 \mathrm{mM}$ sodium phosphate buffer ( $\mathrm{pH}$ 6.0). The column was eluted at a flow rate of $0.3 \mathrm{~mL} / \mathrm{min}$ and $5 \mathrm{~mL}$ fractions were collected. The protein content of each fraction was determined by measuring the absorbance at $280 \mathrm{~nm}$. The fractions with enzyme activity were pooled and dialysed overnight against distilled water and then used in all subsequent experiments.

\section{Enzyme characteristics, Effects of Temperature and pH on Enzyme Activity and Stability}

The optimum temperature for the activity of the purified enzyme was determined by assaying the milk-clotting activity at intervals of $5^{\circ} \mathrm{C}$ from 30 $85^{\circ} \mathrm{C}$. The optimum $\mathrm{pH}$ for the activity of the purified enzyme was determined by assaying the milk-clotting activity in the $\mathrm{pH}$ range $5.5-8.5$, by adjusting the $\mathrm{pH}$ of the substrate (skim milk) with $0.1 \mathrm{M} \mathrm{HCl}$ or $0.1 \mathrm{M} \mathrm{NaOH}$ as appropriate. The maximum milk-clotting activity obtained was taken to be $100 \%$. To determine the thermal stability, the purified enzyme was incubated at $5^{\circ} \mathrm{C}$ intervals from $40-70^{\circ} \mathrm{C}$, and the length of the incubation was varied from 0 to $40 \mathrm{~min}$. After incubation, the residual milk-clotting activity was determined and the activity obtained with an incubation time of 0 min was taken to be $100 \%$. To determine the $\mathrm{pH}$ stability, the enzyme was dispersed $(1: 1, \mathrm{v} / \mathrm{v})$ in the $0.1 \mathrm{M}$ buffer solutions at different $\mathrm{pH}$ levels $(\mathrm{pH} 2-9)$. The MCE produced by Mucor pusillus $Q M 436$, held at $30{ }^{\circ} \mathrm{C}$ for $30 \mathrm{~min}$. and the residual milkclotting activity was determined and the maximum activity obtained was taken to be $100 \%$.

\section{Effect of Substrate Concentration}

The effect of substrate concentration on the milk-clotting activity of the purified enzyme was determined by increasing the concentration of the skim milk from 25 to $200 \mathrm{~g} / \mathrm{L}$. The maximum activity obtained was taken to be $100 \%$.

\section{Effect of $\mathrm{NaCl}$ Concentration}

In the manufacture of Domiati cheese, the most popular soft variety in Egypt, salt is added directly to milk before renneting in concentrations ranging from 9 to $15 \%$. Accordingly, the effect of sodium chloride on the milk clotting activity of the enzyme from M. pusillus QM 436 was studied. Various concentrations of sodium chloride namely $0.0,3.0,5.0,7.5,10.0$ and $15.0 \%$ 
were incorporated in the reconstituted skim milk to be tested for enzyme clotting activity

\section{Effect of calcium on milk-clotting activity}

To study the effect of calcium on clotting efficiency of the purified enzyme, assay was carried out with different concentrations of calcium (0.0, $200,370,550,700,1100$ and 1600 p.p.m.) in the reaction mixture. Time taken for appearance of first clot was noted down and compared with control. Effect of some cations on milk-clotting activity

The effect of metal ions Mn2+, $\mathrm{Zn2+}, \mathrm{Mg} 2+, \mathrm{Cu} 2+, \mathrm{Fe} 3+$ and Ammonium ions on the milk clotting activity was determined at metal ion concentrations of $1 \mathrm{mM}$.The milk-clotting enzyme was incubated at room temperature for $40 \mathrm{~min}$ with metal ions. The milk-clotting activity obtained without metal ions was taken to be $100 \%$.

\section{Michaelis-Menten Constant}

Solutions of casein at concentrations in the range $0.2-2 \%$ in $20 \mathrm{mM}$ potassium phosphate buffer $(\mathrm{pH}$ 6.5) were used as the substrate and the proteolytic activity was determined as described Otani et al. (1991). The Michaelis-Menten constant $\mathrm{Km}$ was calculated from the double reciprocal Lineweaver-Burk plot (Lineweaver and Burk (1934).

\section{RESULTS AND DISCUSSION}

\section{Screening for milk-clotting activity}

A preliminary screening was done to detect the ability of examined cultures to clot milk. Tables ( 3,4 and 5$)$ show the milk clotting enzymes produced by a total of 19 fungi for different period namely 3, 6 and 9 days, respectively. Also the same tables show the effect of varied concentrations of $\mathrm{NaCl}$ on the milk clotting enzymes production by the same collection of fungi. The enzyme was produced by Aspergillus oryzae DSM 633, Aspergillus flavus DSM 818, Aspergillus terreus NRRL 555, Aspergillus vesicolor NCL, Aspergillus tamari NCL, Mucor pusillus QM 346, Rhizopus chinensis DSM6 1834, Rhizopus stolonifer DSM 6855 , Rhizopus nigricans DSM 907, Penicillium citrinum DSM 62851, Penicillium lilacinm MCL, Penicillium implicatum MCL and Penicillium verrucosum MCL. The incubation period for 3 days at $30 \mathrm{oC}$ was found better for Milk clotting activities than 6 and 9 days, respectively. However, $15 \% \mathrm{NaCl}$ concentration stimulate the highest production of Milk clotting activities by Mucor pusillus QM 346 culture. Similar observation were reported by Suganthi, et al. (2012) on producing milk-clotting enzymes by culture of Aspergillus niger. 
Table 3. Screening tests for the production of milk clotting enzymes in whey media containing varying concentrations of sodium chloride after 3 days of incubation.

\begin{tabular}{|c|c|c|c|c|c|}
\hline \multirow{3}{*}{ Fungi cultures } & \multicolumn{5}{|c|}{ concentration of $\mathrm{NaCl}(\%)$} \\
\hline & 0.0 & 5 & 7.5 & 10 & 15 \\
\hline & \multicolumn{5}{|c|}{ Milk clotting activity (MCA) } \\
\hline A. oryzae & 8 & 0 & 0 & 0 & 0 \\
\hline \multirow{2}{*}{$\begin{array}{l}\text { A. niger } \\
\text { A. awamori }\end{array}$} & 0 & 0 & 0 & 0 & 0 \\
\hline & 0 & 0 & 0 & 0 & 0 \\
\hline A. flavus & 3.5 & 0 & 3.8 & 0 & 0 \\
\hline & 4.6 & 3.4 & 0 & 0 & 0 \\
\hline & 0 & 0 & 0 & 0 & 0 \\
\hline \multirow{2}{*}{$\begin{array}{l}\text { A.vesicolor } \\
\text { A.tamarii }\end{array}$} & 22.2 & 3.4 & 0 & 0 & 0 \\
\hline & 40 & 21 & 36.3 & 5.6 & 2.2 \\
\hline \multirow{2}{*}{$\begin{array}{l}\text { A. fumigates } \\
\text { M. pusillus }\end{array}$} & 0 & 0 & 7.4 & 0 & 0 \\
\hline & 40 & 80 & 100 & 133 & 200 \\
\hline $\begin{array}{l}\text { M.hiemalis } \\
\text { R.oryazae }\end{array}$ & 0 & 0 & 0 & 0 & 0 \\
\hline \multirow{2}{*}{ R.oryazae } & 0 & 0 & 0 & 0 & 0 \\
\hline & 22.2 & 12.5 & 8.8 & 6.1 & 12.5 \\
\hline \multirow{2}{*}{$\begin{array}{l}\text { R.stolonifer } \\
\text { R. nigricans }\end{array}$} & 0 & 0 & 0 & 0 & 0 \\
\hline & 0 & 0 & 0 & 0 & 0 \\
\hline \multirow{4}{*}{$\begin{array}{l}\text { P. citrinum } \\
P . \text { lilacinm } \\
\text { P.implicatum } \\
\text { P.verrucosum }\end{array}$} & 0 & 0 & 0 & 0 & 0 \\
\hline & 44.4 & 0 & 0 & 0 & 0 \\
\hline & 6.1 & 40 & 4.7 & 23.5 & 2.2 \\
\hline & 0 & 0 & 0 & 0 & 0 \\
\hline
\end{tabular}

Where:

M.C.A. = Milk Clotting Activity (Soxhlet Units $/ \mathrm{ml}$ )

Table 4. Screening tests for the production of milk clotting enzymes in whey media containing varying concentrations of sodium chloride after 6 days of incubation.

\begin{tabular}{|c|c|c|c|c|c|}
\hline \multirow{3}{*}{ Fungi cultures } & \multicolumn{5}{|c|}{ concentration of $\mathrm{NaCl}(\%)$} \\
\hline & 0.0 & 5 & 7.5 & 10 & 15 \\
\hline & \multicolumn{5}{|c|}{ Milk clotting activity (MCA) } \\
\hline A. oryzae & 14 & 5 & 0 & 0 & 0 \\
\hline \multirow{2}{*}{$\begin{array}{l}\text { A. niger } \\
\text { A. awamori }\end{array}$} & 0 & 0 & 0 & 0 & 0 \\
\hline & 0 & 0 & 0 & 0 & 0 \\
\hline $\begin{array}{l}\text { A. flavus } \\
\text { A. terreus }\end{array}$ & 5 & 7 & 33 & 27 & 0 \\
\hline \multirow{4}{*}{$\begin{array}{l}\text { A. terreus } \\
\text { A.ochraceus } \\
\text { A.vesicolor } \\
\text { A.tamarii }\end{array}$} & 6 & 4 & 4 & 0 & 0 \\
\hline & 0 & 13 & 0 & 0 & 0 \\
\hline & 5 & 4 & 0 & 0 & 5 \\
\hline & 5.7 & 33 & 50 & 9 & 11 \\
\hline \multirow{2}{*}{$\begin{array}{l}\text { A. fumigates } \\
\text { M. pusillus }\end{array}$} & 5 & 0 & 7 & 0 & 0 \\
\hline & 19 & 28 & 40 & 57 & 133 \\
\hline $\begin{array}{l}\text { M.hiemalls } \\
\text { R.oryazae }\end{array}$ & 0 & 0 & 0 & 0 & 0 \\
\hline \multirow{2}{*}{$\begin{array}{l}\text { R.chinensis } \\
\text { R.stolonifer }\end{array}$} & 0 & 0 & 0 & 0 & 0 \\
\hline & 33 & 16 & 6 & 9 & 10 \\
\hline \multirow{2}{*}{$\begin{array}{l}R . \text { nigricans } \\
P \text {. citrinum }\end{array}$} & 7 & 0 & 5 & 0 & 4 \\
\hline & 9 & 27 & 19 & 25 & 13 \\
\hline \multirow{2}{*}{$\begin{array}{l}\text { P. lilacinm } \\
\text { P.implicatum }\end{array}$} & 7 & 7 & 7 & 22 & 3 \\
\hline & 36 & 7 & 17 & 9 & 0 \\
\hline \multirow[t]{2}{*}{ P.verrucosum } & 9 & 80 & 36 & 40 & 20 \\
\hline & 0 & 9 & 25 & 7 & 20 \\
\hline
\end{tabular}


Table 5. Screening tests for the production of milk clotting enzymes in whey media containing varying concentrations of sodium chloride after 9 days of incubation.

\begin{tabular}{|c|c|c|c|c|c|}
\hline \multirow{3}{*}{$\begin{array}{l}\text { Fungi } \\
\text { cultures }\end{array}$} & \multicolumn{5}{|c|}{ concentration of $\mathrm{NaCl}(\%)$} \\
\hline & 0.0 & 5 & 7.5 & 10 & 15 \\
\hline & \multicolumn{5}{|c|}{ Milk clotting activity (MCA) } \\
\hline \multirow{9}{*}{$\begin{array}{l}\text { A. oryzae } \\
\text { A. niger } \\
\text { A. awamori } \\
\text { A. flavus } \\
\text { A. terreus } \\
\text { A.ochraceus } \\
\text { A. vesicolor } \\
\text { A.tamarii } \\
\text { A. fumigates }\end{array}$} & 20 & 21 & 4 & 0 & 0 \\
\hline & 0 & 0 & 0 & 0 & 0 \\
\hline & 0 & 0 & 0 & 0 & 0 \\
\hline & 10 & 31 & 67 & 40 & 3 \\
\hline & 15 & 31 & 15 & 3 & 0 \\
\hline & 16 & 57 & 9 & 30 & 0 \\
\hline & 16 & 4 & 0 & 0 & 0 \\
\hline & 67 & 133 & 200 & 22 & 40 \\
\hline & 0 & 3 & 3 & 0 & 0 \\
\hline \multirow{2}{*}{$\begin{array}{l}\text { A. fumigates } \\
\text { M. pusillus } \\
\text { M.hiemalis }\end{array}$} & 13 & 13 & 19 & 21 & 40 \\
\hline & 0 & 0 & 0 & 0 & 0 \\
\hline \multirow{3}{*}{$\begin{array}{l}\text { R.oryazae } \\
\text { R.chinensis } \\
\text { R.stolonifer } \\
\text { R niaricans }\end{array}$} & 0 & 0 & 5 & 0 & 0 \\
\hline & 25 & 27 & 7 & 9 & 15 \\
\hline & 13 & 3 & 4 & 0 & 0 \\
\hline \multirow{4}{*}{$\begin{array}{l}P \text {. citrinum } \\
P \text {. lilacinm } \\
\text { P.implicatum }\end{array}$} & 4 & 13 & 13 & 6 & 3 \\
\hline & 3 & 6 & 0 & 12 & 0 \\
\hline & 57 & 13 & 16 & 10 & 0 \\
\hline & 21 & 200 & 4 & 80 & 27 \\
\hline P.verrucosum & 0 & 9 & 16 & 5 & 5 \\
\hline
\end{tabular}

Table 6. Purification step of milk clotting enzyme from M. pusillus QM 436 using ammonium sulfate and Gel filtration (Sephadex G100)

\begin{tabular}{|l|c|c|c|}
\hline Purification step & Crude enzyme & $\begin{array}{c}(\mathrm{NH} 4) 2 \mathrm{SO} 4 \\
(40-80 \%)\end{array}$ & Sephadex G-100 \\
\hline Volume $(\mathrm{ml})$ & 25 & 11 & 40 \\
\hline MCT $(\mathrm{min})^{*}$ & 8 & 4 & 23 \\
\hline MCA (SU/ml) & 50 & 100 & 17 \\
\hline PC $(\mathrm{mg} / \mathrm{ml})^{\star * *}$ & 6.3 & 7.5 & 0.3 \\
\hline SP.MCA ${ }^{\star * *}$ & 7.93 & 13.33 & 56.66 \\
\hline Total activity units & 1250 & 1100 & 680 \\
\hline Recovery \% & 100 & 88 & 54.4 \\
\hline Ratio purification & 1.0 & 1.68 & 7.14 \\
\hline
\end{tabular}

*MCT: Milk Clotting Time (min), **SU: Soxhlet Units,

${ }^{* \star *}$ PC: Protein Content (mg/ml), ${ }^{* \star \star *}$ SP.MCA: Specific Activity = MCA/PC

\section{Purification and Molecular Mass}

Partial Purification of enzyme from culture supernatant fig. (1) shows flow sheet diagram of the purification steps of rennin like enzyme from $M$. pusillus QM 436 . It was ratio purified 1.68 -fold and $88 \%$ recovery with respect to the crude culture supernatant by precipitation in $40-80 \%$ saturated ammonium sulfate. Passage through a Gel-Sephadex G-100 column eluted purified the enzyme to 7.14 -fold with $54.4 \%$ recovery (Table 6 ). The partially 
purified enzyme was separated into two peaks but with only one having milk clotting activity. Earlier studies reported that the milk-clotting enzymes from different sources have different chromatographic activity results. However, this result was different from the milk-clotting enzyme from Mucor bacilliformis Areces, et al. (1992), where the ion-exchange chromatography elution pattern showed two peaks of proteins but both fractions had milk-clotting activity. Similar results obtained from by Otani, et. al., (1991), Salem, et. al. (1998), Abbas, et al. (1998), Cavalcanti, et. al. (2004), Shieha et. al. (2009) and Xiaoling et al. (2011). Needless to add, that the observed differences recorded in some cases between the present results and those of other investigator could be attributed to variations in both strains and growth the media.

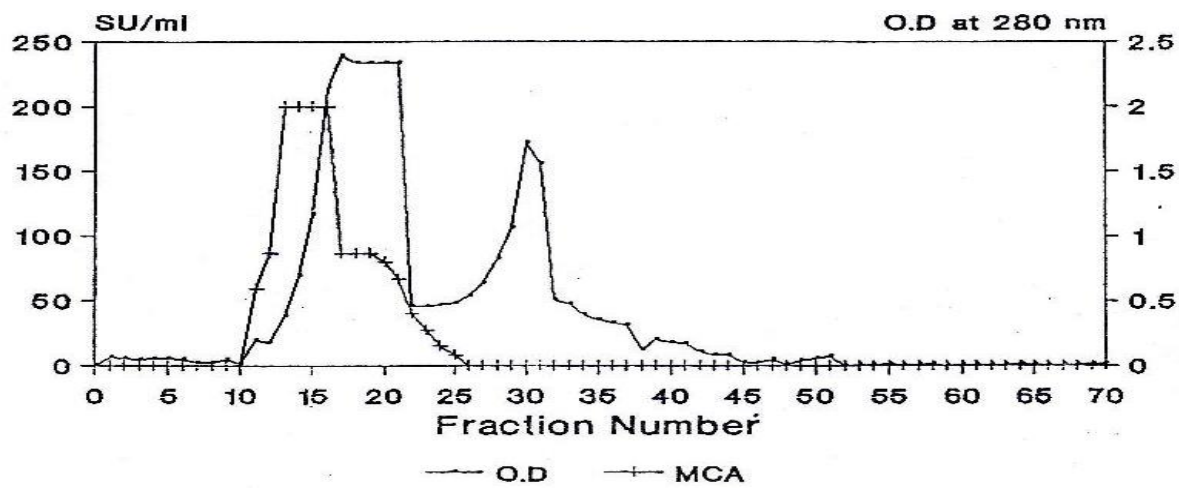

Fig.1: Purification of milk clotting enzyme from M. pusillus $Q M 436$ on Sephadex G-100

\section{Enzyme characteristics, effects of temperature and $\mathrm{pH}$ on enzyme activity and stability}

The milk-clotting activity increased with increased temperature in the temperature range $30-60^{\circ} \mathrm{C}$ and the optimum temperature for the purified enzyme was $60^{\circ} \mathrm{C}$ (Fig.2). Different enzymes have different optimum temperatures, mainly depending on the enzymes' structure. This result was in accord with the milk-clotting enzyme from Bacillus subtilis (natto) Chwen-Jen et. al. (2009) and Bacillus amyloliquefaciens D4 (Xiaoling, et. al. (2011), but different from calf rennet, which has an optimum temperature in the range 40$42^{\circ} \mathrm{C}$. This substantial difference in optimum temperature between the microbial milk-clotting enzyme and calf rennet suggests strongly that they are suitable for use under different conditions. The maximum milk-clotting activity was at $\mathrm{pH} 5.5$ for the purified enzyme, and the activity decreased with increasing $\mathrm{pH}$ (Fig. 3). 

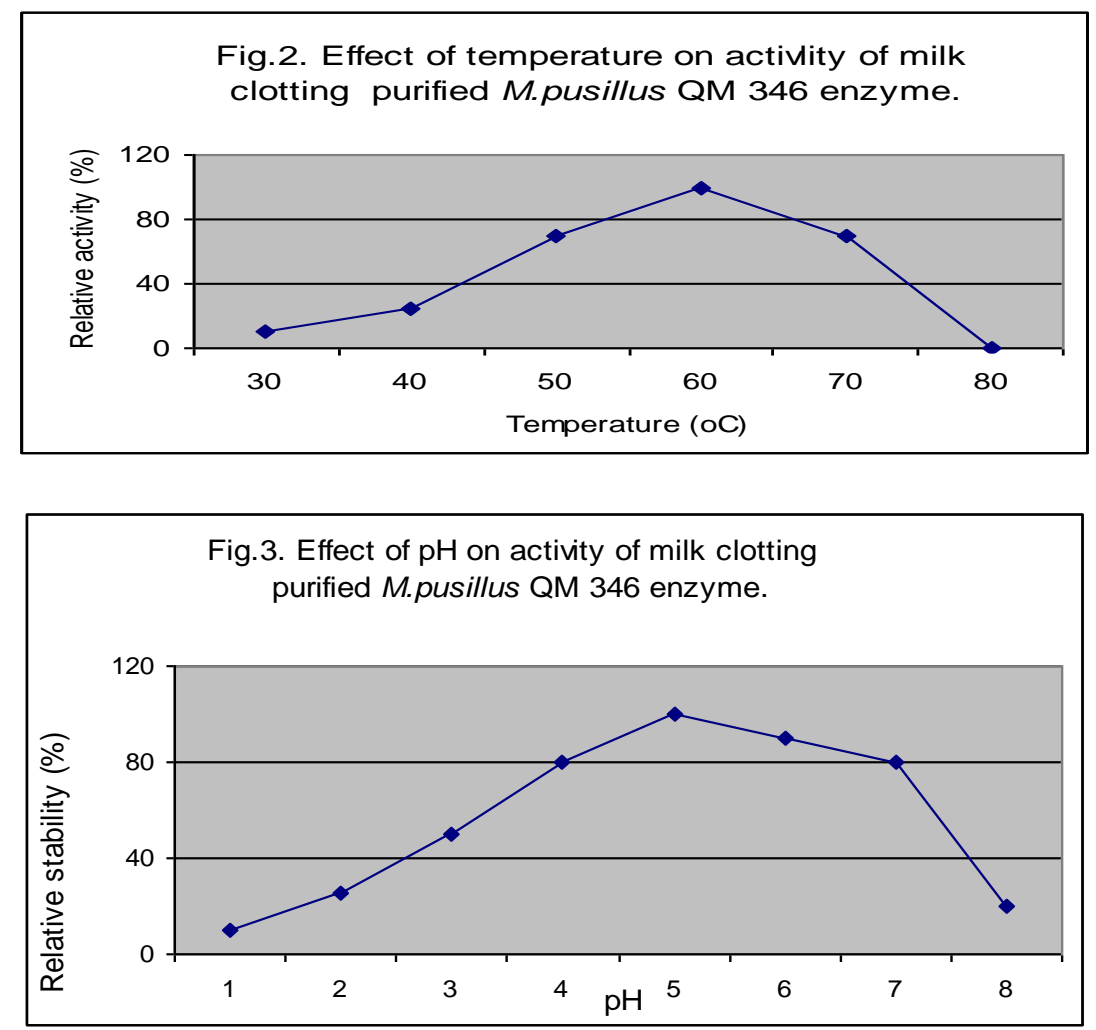

This result was similar to what is reported for the milk-clotting enzymes from Mucor miehei, Rhizopus oryzae Kumar, et. al. (2005) and glutinous rice wine mash liquor Wang, et. al., (2009). Like calf rennet, the purified enzyme from B. amyloliquefaciens D4 had a higher level of milkclotting activity in the acidic range Xiaoling, et. al. (2009). In Fig. 4. is shown the thermal stability of purified milk-clotting enzyme produced by Mucor pusillus QM 436. The purified enzyme retained $96 \%$ of MCA after incubation for $40 \mathrm{~min}$ at $40{ }^{\circ} \mathrm{C}$, and decreased to $47 \%$ after incubation for $40 \mathrm{~min}$ at $55{ }^{\circ} \mathrm{C}$. It was stable up to $45{ }^{\circ} \mathrm{C}$ with more than $90 \%$ of the activity remained after 40 min of incubation, and it was deactivated completely after $5 \mathrm{~min}$ at $70{ }^{\circ} \mathrm{C}$ and $30 \mathrm{~min}$. at $65{ }^{\circ} \mathrm{C}$. The results shown here are comparable to those reported previously for the thermo-stabilities of milk-clotting enzymes MCE (s) produced by various microorganisms.

The MCE by $P$. oxalicum displayed a dramatic loss in activity after 20 min. of incubation at $55^{\circ} \mathrm{C}$ Hashem (2000), and that by M. pusillus (O'Leary and Fox 1974) and Mucor J20 Hosoi and Kiuchi (2004) was completely inactivated after heating at $60 \circ \mathrm{C}$ for $20 \mathrm{~min}$. and $10 \mathrm{~min}$., respectively. In addition, the crude MCE by Nocardiopsis sp. Cavalcanti, et. al. (2004) lost its activity almost entirely when it was incubated at $65{ }^{\circ} \mathrm{C}$ after $30 \mathrm{~min}$. The $\mathrm{pH}$ 
effects on the activity of MCE produced by Mucor pusillus QM 436, are shown in Fig. 5. The results indicated that the purified enzyme retained more than $85 \%$ of its activity between $\mathrm{pH} 4$ and $\mathrm{pH} 7$ and more than $60 \%$ of its activity between $\mathrm{pH} 7$ and $\mathrm{pH} 9$ for more than $30 \mathrm{~min}$. at $30 \circ \mathrm{C}$, but the activity decreased dramatically below $\mathrm{pH} 4$. In addition, the optimum $\mathrm{pH}$ for the purified enzyme is at $\mathrm{pH} 6$, which is different from those of milk-clotting enzymes produced by various microorganisms.
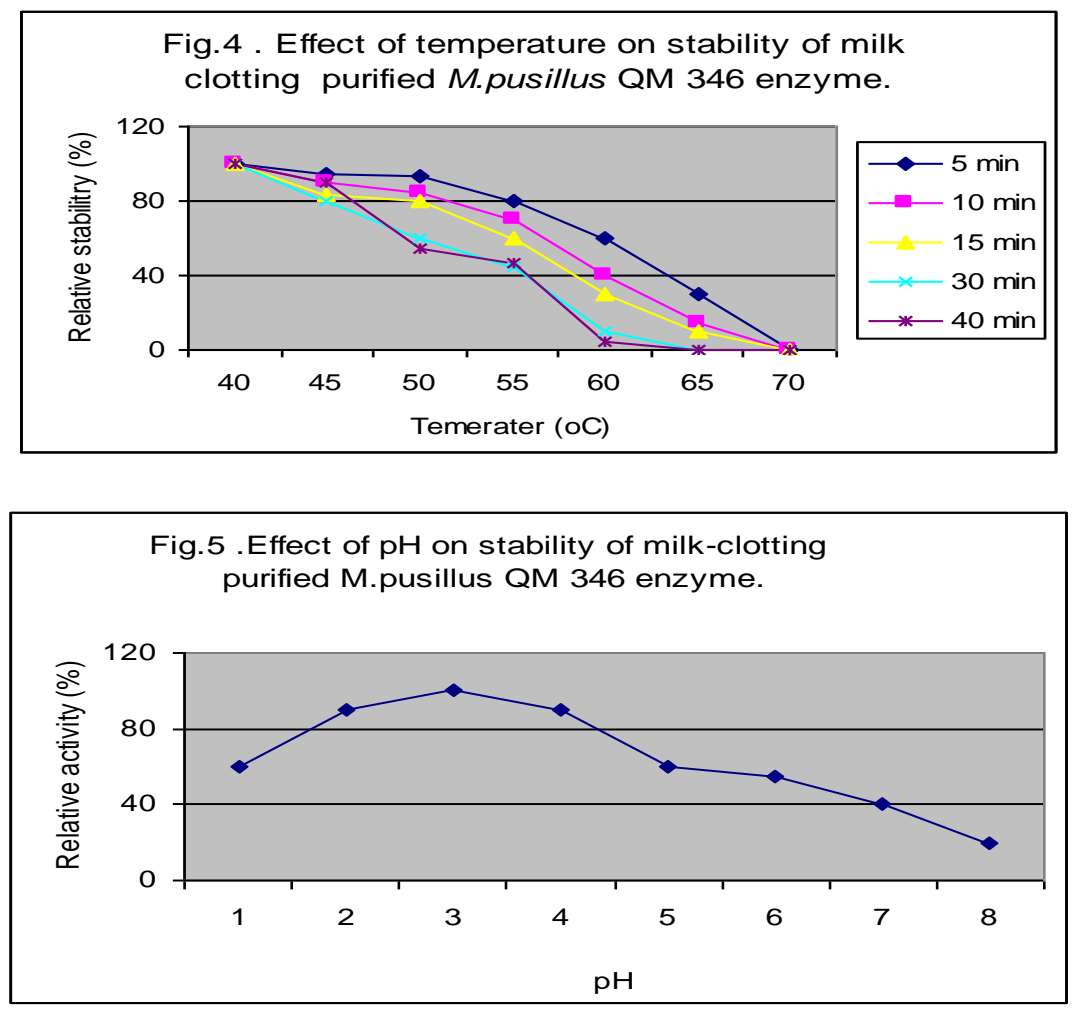

The optimum $\mathrm{pH}$ for the MCE of $P$. oxalicum Hashem (2000), $M$. baciliformi Venera, et al. (1997) and Nocardiopsis sp. Cavalcanti, et. al.,[4] was at $\mathrm{pH} 4, \mathrm{pH} 5.5$ and $\mathrm{pH} 11$, respectively. It is expectant that coagulants should not be sensitive to variations in milk composition and $\mathrm{pH}$ in that the use of highly $\mathrm{pH}$-sensitive rennet can lead to reduced yields and defective cheese due to soft coagulum at cutting Cavalcanti, et. al. (2004). The fact that MCE produced in this study showed a wide rang of $\mathrm{pH}$ stability has added advantage to its usefulness as cheese-making coagulant.

\section{Michaelis-Menten Constant}

The $\mathrm{Km}$ of purified enzyme was $19.5 \mathrm{mg} / \mathrm{ml}$ when casein used as a substrate suggesting a wide specificity of enzyme towards different substrates. Similarly $\mathrm{Km}$ values for milk clotting enzymes from Streptomyces 
remoseus NRRL 12907 were reported to be $20 \mathrm{mg} / \mathrm{ml}$ El-Tanboly and Selim (1995).

\section{Effect of $\mathrm{NaCl}$ Concentration}

Results are shown in Fig. (6) the data indicated that the (MCA) of purified enzyme from M. pusillus QM 436 decreased as the concentration of sodium chloride increased. The relative (MCA) declined sharply from $100 \%$ to $78.3 \%$ with the addition of $3 \%$ Nacl. However, the relative activity decreased smoothly with higher concentration of sodium chloride to reach $23.3 \%$ at $15 \%$ salt. Similar findings are reported in the literature Wang et. al. (1969), Kolaczkowska et. al. (1985), El-Batawy (1991), El-Tanboly and Selim (1995) and El- bendary et. al. (2007) quoted that the (MCA) of both rennin and Rhizopus

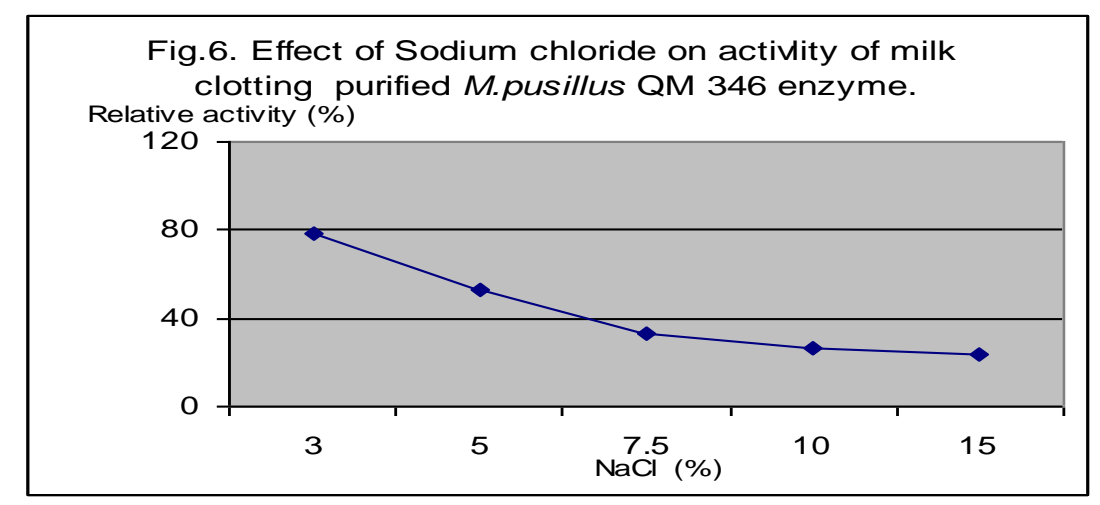

NRRL 3271 enzyme decreased as the concentration of sodium chloride increased. They also added that rennin appeared to be more sensitive to $\mathrm{Nacl}$ than microbial enzyme. In conclusion, the presence of $\mathrm{Nacl}$ in milk, even at low concentrations, would cause appreciable loss in the clotting activity of the studied purified microbial protease. This may be taken into consideration when manufacturing Domiati cheese using the previous enzyme.

\section{Effect of calcium on milk-clotting activity}

Calcium chloride is generally added to heated milk in the range from 0.01 to $0.02 \%$ overcome the difficulties sometimes encountered in the coagulation of such milks. This is regularly done in European countries where the milk is usually pasteurized at $75-80^{\circ} \mathrm{C}$ for $12-20$ seconds. Results are shown in the Fig. 7. it could be observed that a positive and proportional relationship occurred between the clotting activities of the purified enzyme from M.pusillus QM 436 and the CacL2 concentration within the range tested from 0 to 1600 p.p.m. In the other words, as the $\mathrm{Ca}++$ ion concentration increased the clotting activity increased in a proportional manner. 


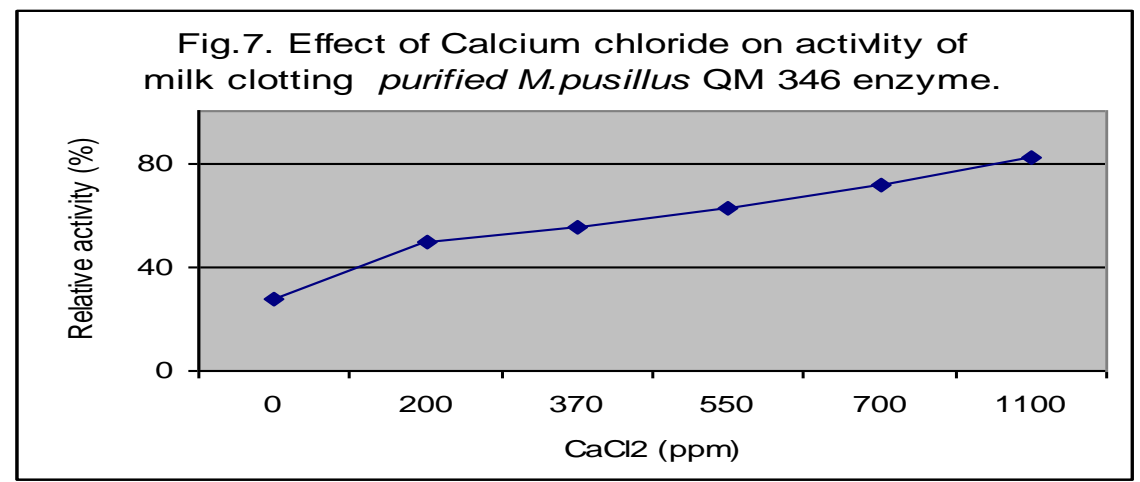

Iwasaki et al. (1967), Kolaczkowska et al. (1985) and Najera et. al. (2003) arrived to the same conclusion with $M$. pusillus protease which increased in its clotting activity the increase in $\mathrm{Ca}++$ ion. Park et. al. (1987) and Selim et. al. (1991) noted that the clotting time decreased progressively with increasing Cacl 2 concentrations, the percentage of reduction with $25 \mathrm{mg}$ Calcium $/ 100 \mathrm{ml}$. milk was $41 \%$ with Mito rennet from M. pusillus lindt. Ismail et. al. (1978), ElBatawy (1991), Kumar et al. (2005) and El-Bendary et al. (2007) reported that the purified enzyme from $A$. ochraceus (MCA) was greatly enhanced by manganous ions and by increasing concentration of Cacl2. Addition of calcium also reduces $\mathrm{pH}$ of milk solution thereby hastening protein aggregation Mehaia and Cheryan (1983) Gastaldi et al. (1994). Curd firmness, gel strength, aggregation rate, and adhesiveness are improved with the addition of calcium Patel and Reuter (1986); Solorza and Bell (1998) and Cavalcanti et al. (2004).

\section{Effect of some cations on milk-clotting activity}

From Fig. (8) it is evident that most cations gave no effect on the enzyme activity at the concentration tested except Cu2+ which proved to be a potent inhibitor. On the other hand, $\mathrm{Mg} 2+$ and $\mathrm{Fe} 3+$ showed a pronounced effect on relative activity reached about $109 \%$. These results were similar to those reported by Kurutahalli et al. (2010).

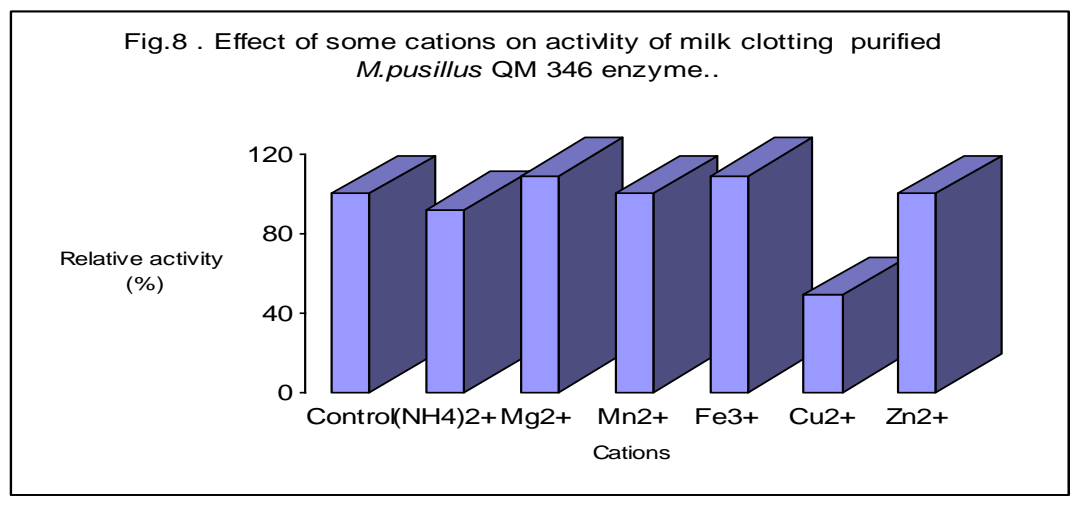




\section{A comparison of activities of some of the rennets}

A comparison of activities of some of the rennets is listed in table 7. Purified milk-clotting enzyme from Mucor pusillus QM 436 has an MC/P ratio of 1.81 in comparison to 7 in case of recombinant camel chymosin Kappeler et al. (2006). Other proteases had an MC/P ratio in the range of 0.05 to 2.1. Thus, milk-clotting enzyme form Mucor pusillus QM 436 showed medium activity and high MC/P ratio, when compared to other commercial rennets.

Table 7. Comparison of the MCA produced by Mucor pusillus QM 436 with commercial rennet.

\begin{tabular}{|l|c|c|c|}
\hline \multicolumn{1}{|c|}{ Rennet source } & MCA & PA & MC/PA \\
\hline Calf rennet (sigma) & 100 & 100 & 1 \\
\hline Mucor rennet (sigma) & 11.3 & 126 & 0.089 \\
\hline M. pusillus proteasea & 33 & 147 & 0.22 \\
\hline FPCC & 170 & 25 & 7 \\
\hline Piglet chymosina & 25 & 12 & 2.1 \\
\hline M. meihei proteasea & 19 & 149 & 0.13 \\
\hline Bovine pepsina & 124 & 2,731 & 0.05 \\
\hline Mucor pusillus rennet & 20 & 11 & 1.81 \\
\hline MCA , PA (\% of calf rennet), & *FPCC fermentation produced camel chymosin , From
\end{tabular}
reference (Kappeler et al. (2006).

\section{CONCLUISSON}

It could be concluded that dairy companies wastes (salted whey resulting from Ras cheese manufacture) could be used as a cheap whole medium for growth Mucor pusillus QM 436, to produce milk-clotting enzyme, in addition to prevent the pollution of environment. These enzymes possessed high milk-clotting activity and low proteolytic action could be applied in manufacture of different cheese as calf rennet substitutes.

\section{REFERENCES}

Abbas, H.M., Foda, M.S., Nadia M. Shahein and Maysa Moharam (1998). Utilization of Rhizopus oligosporus milk clotting enzyme in the manufacture of Domiati cheese. Egyptian J. Dairy Sci., 26: 263-270.

Areces, L.B., Biscoglio de Jiménez Bonino, M.J., Parry, M.A.A., Fraile, E.R.,. Fernandez, H.M. and Cascone, O. (1992). Purification and characterization of a milk-clotting protease from Mucor baciliformis, Appl. Biochem. Biotechnol. 37 283-294.

Briczinski, E.P. and R. F. Roberts (2002) Production of an Exopolysaccharide-Containing whey protein concentrate by fermentation of whey. Journal of Dairy Science. 85: 3189.

Cavalcanti, M.T.H., Teixeira, M.F.S., Lima Filho, J. L. and Proto, A.L.F. (2004). Partial purification of new milk clotting enzyme produced by Nocardiopsis sp. Bioresource Technology. 93: 29-35.

Chwen-Jen Shieha, Lan-Anh Phan Thib and Ing-Lung Shihb (2009). Milkclotting enzymes produced by culture of Bacillus subtilis natto. Biochemical Engineering Journal 43, 85-91. 
El-Batawy, M. A. (1991). Some factors affecting the clotting activity of adult camel rennet. Egyptian J. Dairy Sci. 19: 17.

El-Bendary, M. A., Moharam, Maysa. E. and Ali, Thanaa. H. (2007). Purification and characterization of milk clotting enzyme Produced by Bacillus sphaericus. Journal of Applied Sciences Research. 3(8):695699.

El-Tanboly, E.E. and Selim, M.H. (1995). Studies on milk clotting enzymes produced by Strptomyces II. Purification and properties of milk clotting enzymes from Strptomyces remoseus NRRL 12907. J. Agric. Sci. Mansoura Univ. 20: 4731.

Gastaldi E, Pellegrini O, Lagaude A, Tarodo de la Fuente B (1994). Functions of added calcium in acid milk coagulation. J Food Sci. 59:310-320.

Hashem, A. m. (2000). Purification and properties of a milk-clotting enzyme produced by Pencilium oxalicum. Bioresource Technology. 75: 219222.

Hosoi, T., and Kiuchi, K. (2004). Production and probiotic effects of natto, in: E. Ricca, A.O. Henriques, S. Cutting (Eds.), Bacterial Spore Formers: Probiotics and Emerging Applications, Horizon Bioscience, Norwich, UK, (Chapter 12).

Ismail, A. A., Foda, M.S., and Khorshid, M.A. (1978). Purification and properties of rennin like enzyme from Aspergillus ochraceus. Zbl. Bakt. II. Abt., Bd. 133, S. 321-328.

Iwasaki, s., Yasui, T., Tamura, G. and Arima, K. (1967). Milk clotting enzyme from microorganisms. III. The purification of the enzyme and its properties. Agr. Biol. Chem. 31 (12): 1421-1426.

Kappeler SR, van den Brink HJ, Rahbek-Nielsen H, Farah Z, Puhan Z, Hansen EB, Johansen E (2006). Characterization of recombinant camel chymosin reveals superior properties for the coagulation of bovine and camel milk. Biochem Biophys Res Commun 342:647-654.

Kawai, M and Mukai, N (1970). Studies on milk-clotting enzyme produced by Basidomycetes. 1. Screening tests of Basidomycetes for the production of milk-clotting enzymes, Agric. Biol. Chem. 34 159-163.

Kolaczkowska, M. Chrzanowska, J. Piasceki, E. Jacyk, A. and Polanowski, A. (1985). Isolation and properties of rennin like enzyme from Fusarium moniliform. Milchwissenschaft. 40:153.

Kumar S, Shama NS, Saharan MR, Singh R. (2005) Extracellular acid protease from Rhizopus oryzae: purification and characterization. Proc. Biochem. 4:1701-1705.

Kurutahalli S. Vishwanatha and A. G. Appu Rao (2010).Production and characterization of a milk-clotting enzyme from Aspergillus oryzae MTCC 5341. Appl Microbiol Biotechnol . 85:1849-1859.

Lineweaver, H., and D. Burk (1934). The enzyme determination of enzyme dissociation constants. J. Amer. Chem. Soc. 56:658.

Mehaia M. A, Cheryan M. (1983). Coagulation studies of ultra filtration concentrated skim milk. Milchwissenschaft 38:708-710. 
Najera, A.i., Renobales, M., and Barron, L.J.R. (2003). Effect of pH, temperature, $\mathrm{CaCl} 2$ and enzyme concentrations on the rennet-clotting properties of milk A Multi factorial study. Food chemistry. 80: 345-352.

O'Leary, P.A. and Fox, P.F. (1974). A method for the quantitative analysis of the enzyme complement of commercial rennets, J. Dairy Res. 41, 381-387.

Ohnishi, S.T. and Barr, J.K. (1978). A simplified method of quantitating protein. The buiret and phenol reagents. Anal. Biochem. 86: 193.

Otani, H., Mitsuhiro, I. and Akiyoshi Hosono (1991). The screening of trees having milk activity. Anima. Sci. Tech. 62: 417.

Park, Y. W., Kobayashi, H., Kusakabe, I. and Murakami, K. (1987). Purification and characterization of soy milk -clotting enzyme from $B$. sp. K-295 G-7. Agric. Biol. Chem. 51: 2349.

Patel RS, Reuter H (1986) Effect of sodium, calcium and phosphate on properties of rennet coagulated milk. Lebensmittel Wissenschaft Technologie 19:288-291.

Salem, M.M., Murad, H.A. and El-Tanboly, E.E. (1998). A salt tolerant strain of Mucor spp. For production of milk clotting enzyme from salted whey. Egyp. J. Dairy Sci., 26: 39-50.

Sanderson, W. B., A. P. Brady, G. F. Whitehead, I. J. Oldham, and I. P. Brockwell (1996) Recycling salt solution in cheese processing and apparatus therefore. Murray Goulburn Co-Operative Co. Limited, Australia, assignee. US Pat. No. 5,73,237.

Selim, M.H., El-Shafei, A.M., Tawfek, N.F. and Sharaf, O.M. (1991). Milk clotting enzyme from Bacillus stearothermophillus. Egyptian J. of Microbiology 26: 403.

Shieh CJ, Phan Thi LA, Shih IL (2009), Milk-clotting enzymes produced by culture of Bacillus subtilis natto. Biochem. Eng. J. 43: 85-91.

Solorza FJ, Bell AE (1998) The effect of calcium addition on the rheological properties of a soft cheese at various stages of manufacture. Int J Dairy Technol 51:23-29.

Suganthi, R., Hari, A., Arumugam, B.,Arungopal, M., Ramesh Kumar, V.,Fathima Benazir, J. (2012). Aspergillus niger- A potential enzyme producer on cost effective agro industrial wastes. Research Journal of Biotechnolog.

Venera, G. D., C. Machalinski, C ., H. Zum arraga, M.J. Biscoglio de Jiménez Bonino, (1997). Further characterization and kinetic parameter determination of a milkclotting protease fromMucor bacilliformis, Appl. Biochem. Biotechnol. 68, 207-216.

Wang, Hawal, Ruttle, Dorris, I. and Hesseltine, C.W. (1969). Milk clotting activity of proteinases produced by Rhizopus. J. Microbial 15: 99-104.

Wang Y, Cheng Q, Ahmed Z, Jiang X, Bai X (2009). Purification andpartial characterization of milk-clotting enzyme extracted from glutinous rice wine mash liquor. Korean J. Chem. Eng. 26: 1313-1318.

Xiaoling He, Fazheng Ren, Huiyuan Guo, Weibing Zhang, Xi Song and Bozhong Gan (2011) Purification and properties of a milk-clotting 


\section{EI - Tanboly, E. E. et al.}

enzyme produced by Bacillus amyloliquefaciens D4. Korean J. Chem. Eng., 28 (1), 203-208.

Zayed, G., and J. Winter. (1995) Batch and continuous production of lactic acid from salt whey using free and immobilized cultures of lactobacilli. Applied. Microbiology Biotechnology. 44:362.

Zhang, X., R. L., Kilmer and A. Muhammed. (2003) A descriptive analysis of Egypt and Saudi Arabia import United States dairy products. International Agriculture Trade and Policy Center, Florida Univ.

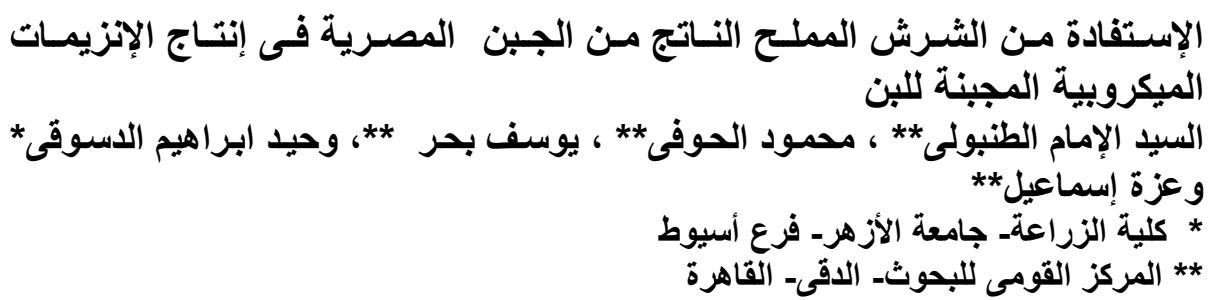

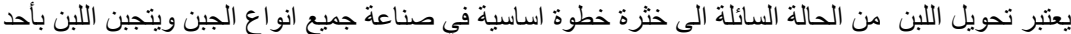

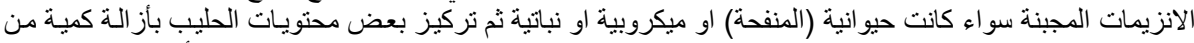

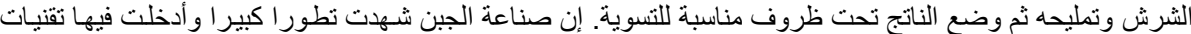

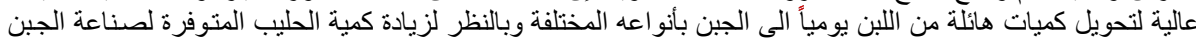

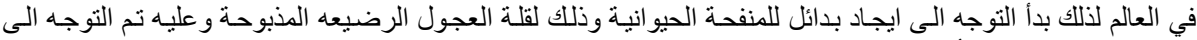

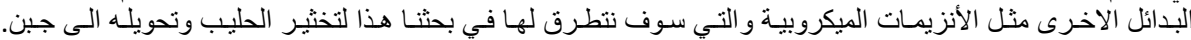

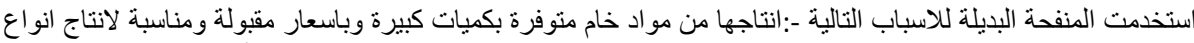

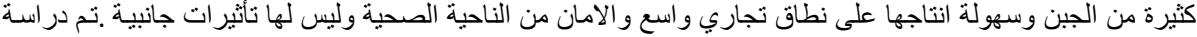

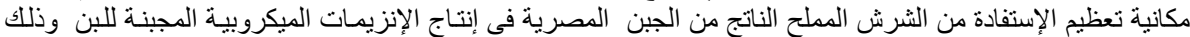

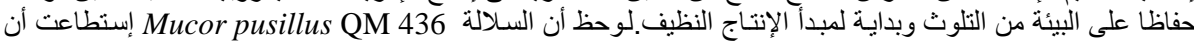

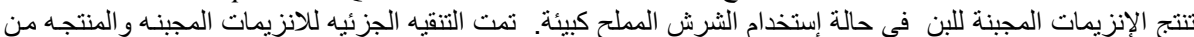

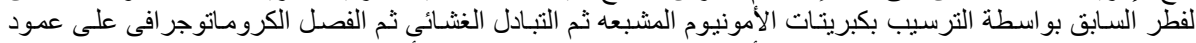

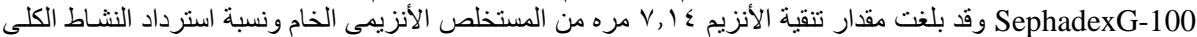

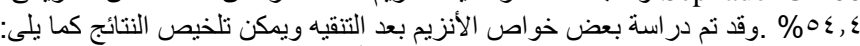

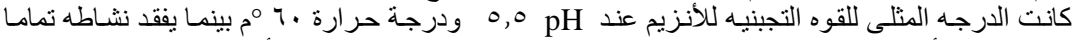

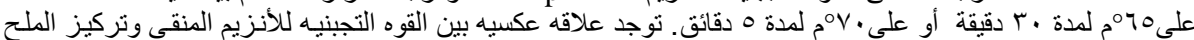

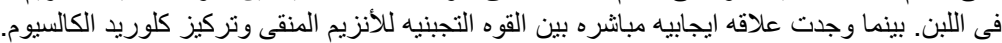

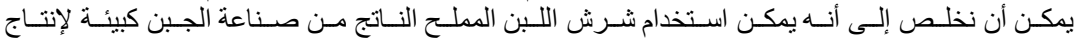

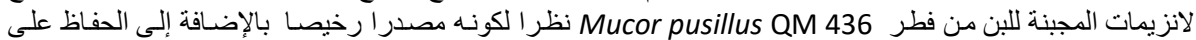

كلية الزراعة - جامعة المنصورة

كلية الزراعة - جامعة أسيوط
قام بتحكيم البحث

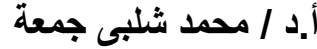

أ.د / فتحى السيد الجزار 